\title{
Influence of weather parameters on alternaria leaf blight severity of makhana under the agro-climate of Koshi region of Bihar
}

\author{
SANTOSH KUMAR ${ }^{1 *}$, MD. NADEEM AKHTAR ${ }^{2}$, SANTOSH KUMAR ${ }^{3}$, MAHESH KUMAR ${ }^{4}$ \\ and TRIBHUWAN KUMAR ${ }^{4}$ \\ ${ }^{1}$ Department of Plant Pathology, Mandan Bharti Agriculture College, Agwanpur, Saharsa -852 201, Bihar \\ ${ }^{2}$ Krishi Vigyan Kendra, Agwanpur, Saharsa -852 201, Bihar \\ ${ }^{3}$ Agronomy, Regional Research Station, Agwanpur, Saharsa-852 201, Bihar \\ ${ }^{4}$ Department of Molecular Biology and Genetic Engineering, Bihar Agricultural University, Sabour, Bihar. \\ *Corresponding author: santosh35433@gmail.com
}

\begin{abstract}
Weather parameters play a pivotal role in the infection process and spread of pathogen. It also influences the expression of susceptibility/resistance of the host plant during post-infection phases. Therefore, an experiment was conducted for two consecutive cropping seasons (2018 \&2019) to study the influence of weather parameters such as temperature, humidity, rainfall and wind direction on the emergence of alternaria leaf blight of makhana in Koshi region of Bihar. Maximum per cent disease severity of alternarialeaf blightwas observed during the peak monsoon months (June to August). Highest disease severity of leaf blight $(14.80 \% \& 15.7 \%)$ was observed in the mid June during crop season, 2018 and 2019 . High temperature $\left(36.9^{\circ} \mathrm{C} \& 38.1^{\circ} \mathrm{C}\right)$, and relative humidity $(94 \% \& 96.4 \%)$ of both the year 2018 and 2019 were found correlated with higher severity to alternaria leaf blight. Similarly average HTR values (3.1) were also found correlated with the average high temperature and relative humidity of both years (2018 and 2019) in terms of severity of leaf blight disease. Maximum temperatures, relative humidity and rainfall exhibited strong positive linear relationship and influenced the occurrence of alternaria leaf blight disease significantly. We also developed a geo-phytopathological model for the prediction of alternaria leaf blight disease of makhana on the basis of congenial mean temperature and relative humidity.
\end{abstract}

Keywords : Alternarialeaf blight, makhana, weather parameters, correlation

Makhana (Euryale ferox Salisb) is an imperative shallow annual aquatic cashcrop, commonly known as 'fox nut' or 'gorgon nut'. It belongs to family Nympheaceae and has large floating leaves and prickly petioles that grow in stagnant perennial water bodies generally around $1.5 \mathrm{~m}$ deep, occurring within a wetland ecosystem. It has great value for its nutritional, medicinal and ritualistic significance and support cottage industry providing livelihood to thousands of fishing families. Its cultivation is limited to tropical and sub-tropical regions of South East and East Asia. However, wild form of makhana occurs in Japan, Korea, Bangladesh, China, North America, Nepal, and Russia (Shankar et al., 2010). North Bihar, lower Assam region, West Bengal, Odisha, Manipur, Jammu \& Kashmir and Meghalaya are probably the only states where the makhana is cultivated for commercial purpose as high value commodity (Kumar et al., 2011). It is cultivated in an area of about
20,000 ha and out of which Bihar contributes about 80 per cent acreage and more than 90 per cent production (Jana, 2017). It has also been noticed that North Bihar ranked first not only in India but also in the world. Darbhanga and Madhubani districts of Bihar are the traditional centers for makhana cultivation and processing. Despite the potential role of makhana in the Indian economy, its productivity is affected to a great extent by the outbreak of alternaria leaf blight disease incited by Alternaria alternata (Haidar and Nath, 1987; Dwivedi et al., 1995). This disease is ubiquitous in all the makhana growing areas and causes considerable loss in yield. The symptoms associated with leaf blight included the appearance of small, light brown necrotic lesion surrounded with circular rings, first visible towards margin of leaves. Gradually these lesions coalesced to form large dark blighted area and began to cover entire leaf. Severe infections led to blighting of leaves under favorable 
environmental conditions. Seeds produced by infected plants were grey to black in color, wrinkled, small in size and had low viability. Pathogenesis/disease cycle of leaf blight in makhana and inoculums production is highly dependent on prevailing weather variables. Understanding the influence of weather factors on host stage and disease development is prerequisite to strategically manage the disease. More over no reports are available on epidemiological aspects of this disease till date to the best of my knowledge. Therefore, the present investigation has been undertaken to study the correlation between alternaria leaf blight disease and weather parameters and to develop a geo-phyto-pathological model.

\section{MATERIALS AND METHODS}

The experiment was conducted during two consecutive cropping seasons i.e. 2018 and 2019 at experimental farm, Mandan Bharti Agricultural College, Agwanpur, Saharsa. This farm is geographically located at $25.88^{\circ} \mathrm{N}$ latitude and $86.6^{\circ} \mathrm{E}$ longitude and an at average elevation of 41 meters above the mean sea level in the North Eastern alluvial plains of Bihar forming part of the Koshi river basin. Seedlings of susceptible makhana cultivar were transplanted into the experimental pond/s under recommended agronomical practices except disease management practices. Per cent severity of alternaria leaf blight was recorded from second fortnight of March to mid of August(2018 and 2019) in experimental ponds at seven days intervals using 0-5 scoring scale (Sharma and Kolte, 1994). Where, $0=$ No. of visible symptoms, $1=1-10 \%, 2=11-$ $25 \%, 3=26-50 \%, 4=51-75 \%$ and $5=>75 \%$ leaf area infected. Observations were recorded from ten randomly selected leaves. It was expressed as percent disease index (PDI), which was calculated using a standard formula as given below:

Disease index $(\%)=\frac{\text { Sum of all numerical rating }}{\text { Number of leaves examined } \times \text { Maximum grade }} \times 100$

Disease scores (PDI) were analyzed for correlation and regression with weather parameters to find out the critical weather condition for epidemiology of the disease. Simple correlation between weather variables and disease severity (PDI) was determined as per the standard procedure (Gomez and Gomez, 1984). Meteorological data were obtained from Agro met Field Unit (AMFU), Regional Research Station, Agwanpur, Saharsa which is located at 200 meter distance from the experimental site.

\section{Model development}

Mathematical formula for the HTR model was derived as per the standard method (Jhorar et al., 1992)

$$
\mathrm{HTR}=\mathrm{MRH} / \mathrm{MT}
$$

Where, HTR is the humid thermal ratio,

MRH and MT are the mean relative humidity and the mean temperature respectively.

Three threshold levels for daily HTR values are

(i) When the HTR is between 2.5 and 3.5 , it indicates maximum disease score, (ii) When the HTR is less than 2.0, it indicates least disease score, (iii) When the HTR is more than 3.5 ,it indicates too cold or too wet weather which completely restricts the disease development.

The highly correlated weather variables of Koshi region of Bihar were taken to formulate a geophytopathological model. The HTR model has been developed and validated using data of two consecutive years (2018 and 2019).

\section{RESULTS AND DISCUSSION}

\section{Study of weather parameters and its influence onseverity of leaf blight}

Emergence of alternaria leafblight was influenced by weather parameters and their interactions with the progress of disease right from 30 days of sowing and till the harvesting stage of the crop. Disease speeded with the passage of time and reached its maximum level on 150 days in the crop cycle of 190 days. Weather parameters for the two consecutive years (2018 and 2019) were collected to establish correlation. The minimum temperature $17.4^{\circ} \mathrm{C}$ and $18^{\circ} \mathrm{C}$ along with minimum relative humidity $54.3 \%$ and $58.0 \%$ was recorded during the early stage of the crop and the maximum temperature $36.9^{\circ} \mathrm{C}$ and $37.7^{\circ} \mathrm{C}$ along with maximum relative humidity $94.7 \%$ and $96.4 \%$ was recorded by the end of crop season 2018 and 2019, respectively. The maximum rainfall i.e. $156.7 \mathrm{~mm}$ and $172.9 \mathrm{~mm}$ and the lowest rainfall i.e. 0.00 $\mathrm{mm}$ and $0.00 \mathrm{~mm}$ were received during the harvesting and early stage of the crop growth in 2018 and 2019, respectively (Fig. $1 \& 2$ ). Data analysis of weather parameters for alternaria leaf blight severity infers that high temperature, high relative humidity, high rainfall and eastern wind play an important role in the disease development.Leaf blight severitywas observed in the month April and gradual rise in increasing temperature, relative humidity and rainfall was continued up to the harvesting stage. Highest disease severity of leaf blight was observed in the mid June during both the crop season 2018 and 2019 which was $14.80 \%$ and $15.70 \%$, 


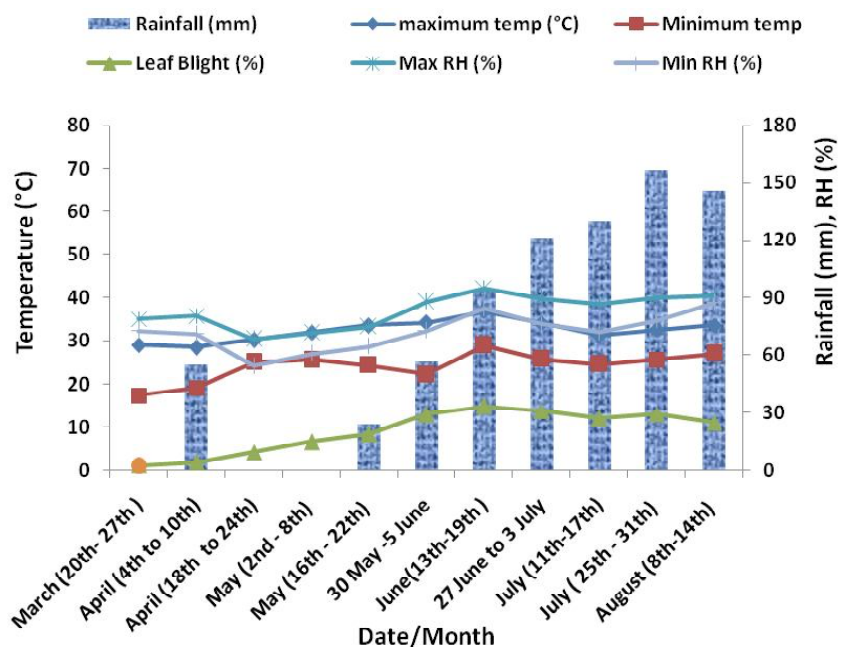

Fig.1: Effect of weather parameters on severity of alternaria leaf blight of makhana at Koshi region during 2018

respectively (Fig. $1 \& 2$ ). Per cent disease severity of leaf blight reached the plateau in the crop season, 2018 during June and August, when maximum temperature range was 31.2 to $36.9^{\circ} \mathrm{C} \&$ minimum temperature range, 22.2 to $27.0^{\circ} \mathrm{C}$ and $\mathrm{RH}$ minimum was 71.8 to $87.5 \%$ \& maximum 87.0 to $94.7 \%$. The same plateau in the crop season, 2019 was observed, when maximum temperature was 32.8 to $38.1^{\circ} \mathrm{C} \&$ minimum temperature 24.3 to $31.6^{\circ} \mathrm{C}$ and $\mathrm{RH}$ minimum was 74.4 to $84.7 \%$ \& RH maximum 83.7 to $96.6 \%$. The rainfall recorded during these three months was 704 and $750 \mathrm{~mm}$ during the crop season 2018 and 2019, respectively. Under dry weather, the progress in disease severity was minimum whereas during moist weather there was increase in leaf blight causing prompt blighting and rotting of entire leaf/ leaves. However not much work has been reported regarding the epidemiology of this disease, but it is also evident from report that $92.0 \% \mathrm{RH}$ is critical for the severe occurrence of leaf spot and heavy losses of betel vine (Das Gupta and Sen, 1985). Chakrabarty (2018) has also reported that the anthracnose leaf spot and bacterial leaf spot of betel vine is maximum when the temperature lies in between 30.6 and $35.1{ }^{\circ} \mathrm{C}$, relative humidity $82 \%$ and $95 \%$ and highest monthly rainfall around $480.1 \mathrm{~mm}$.

\section{Relationship between leaf blight of makhana and weather parameters}

Experimental results of 2018, regression line showed a strong positive linear relationship between disease severity and maximum and minimum temperature having coefficient, $r=0.8604$ and $r=0.7368$ and equation $\mathrm{y}=28.23+0.462 \mathrm{x}$ and $y=19.76+0.460 x$, respectively (Fig. 3a). A strong positive

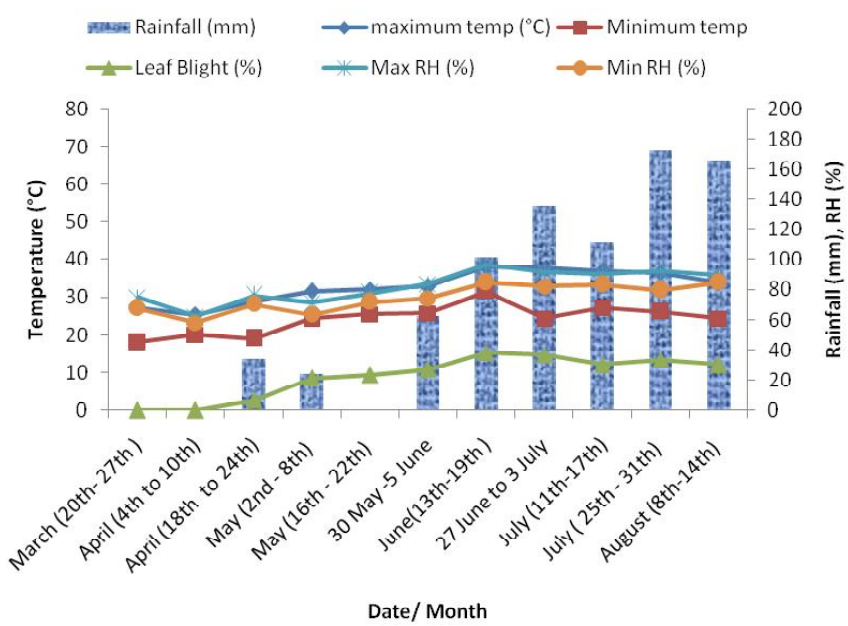

Fig. 2: Effect of weather parameters on severity of alternaria leaf blight of makhana at Koshi region during 2019

linear relationship was observed between disease severity and maximum RH having coefficient, $r=0.7565$ and equation $y=70.92+1.334 x$. However, relationship between disease severity and minimum RH was weak positive correlation having $r=0.5643$ and equation $y=62.45+1.071 x$ (Fig. $3 b$ ). A strong positive linear relationship was observed between disease severity and rainfall with $r=0.73094$ and equation $y=-23.76+10.66 x$ (Fig. 3c). Experimental results of 2019, regression line showed a strong positive linear relationship between disease severity and maximum and minimum temperature having coefficient, $r=0.9635$ and $r=0.8799$ and equation $\mathrm{y}=28.07+0.548 \mathrm{x}$ and $\mathrm{y}=18.76+0.6543 \mathrm{x}$, respectively (Fig. 4a). A strong positive linear relationship was observed between disease severity and maximum $\mathrm{RH}$ having coefficient, $r=0.8714$ and equation $y=70.56+1.568 \mathrm{x}$. However, relationship between disease severity and minimum RH showed weak positive correlation having $r=0.8364$ and equation $y=61.91+1.292 x$ (Fig. 4b). A strong positive linear relationship was there between disease severity and rainfall with $r=0.7718$ and equation $\mathrm{y}=-38.61+14.07 \mathrm{x}$ (Fig. $4 \mathrm{c}$ ). The results of experiment also confirm the earlier reportswhich state that there is positive correlation of temperature with alternaria leaf blight severity (Meena et al., 2011). Similarly, linearpositive correlation with mean rainfall and severity of anthracnose leaf spot has also been noticed (Huq, 2011). There is also report of positive correlation of atmospheric temperature and relative humidity in the development of various diseases (Sindhan and Bose, 1980). In another study positive correlation of maximum temperature (27$\left.28^{\circ} \mathrm{C}\right)$, minimum temperature $\left(14-15^{\circ} \mathrm{C}\right)$ and average relative humidity ( $\geq 65 \%$ ) with alternaria blight severity in mustard 


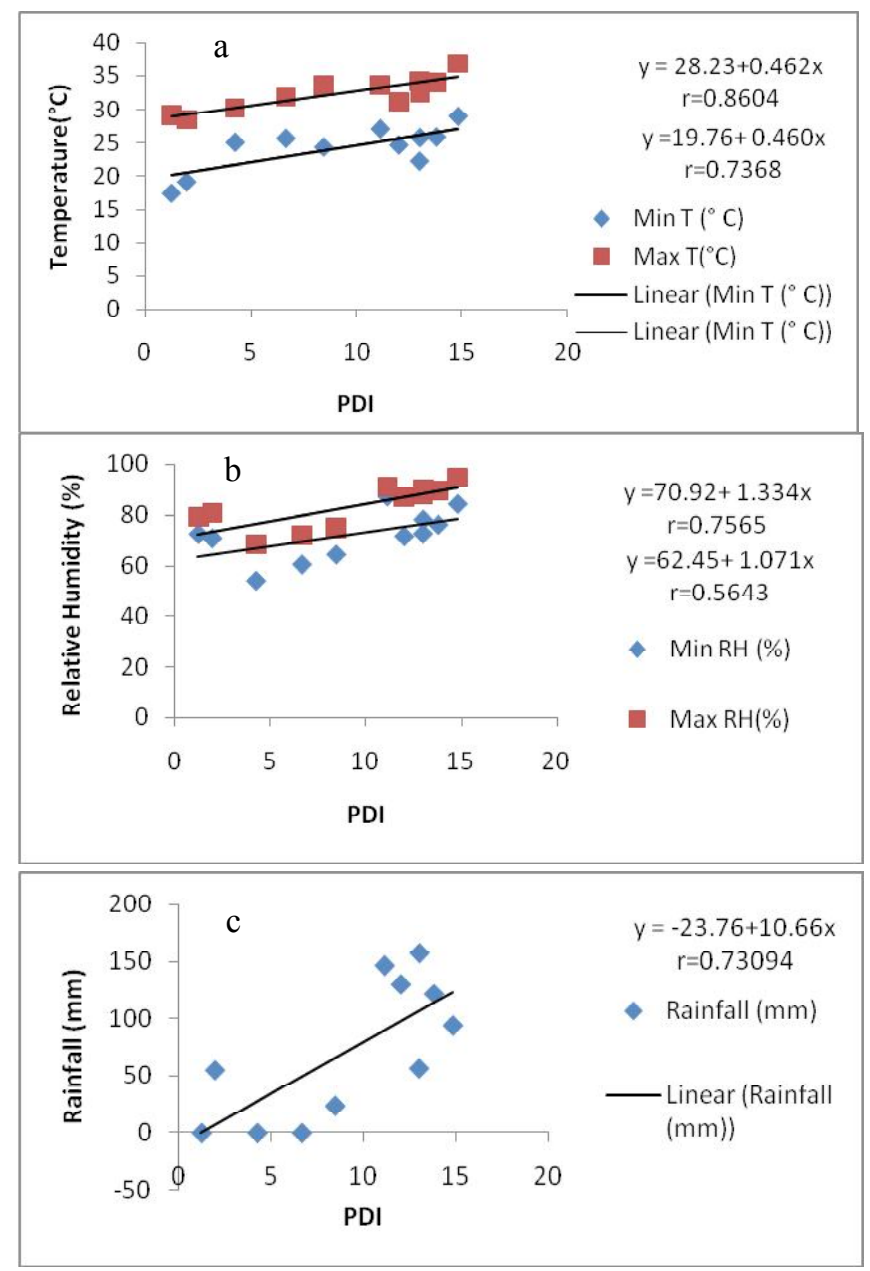

Fig. 3: Relationship between alternaria leaf blight of makhana and weather parameters during 2018;(a) Relationship between temperature and alternaria leaf blight of makhana (b) Relationship between relative humidity and alternaria leaf blight of makhana (c) Relationship between rainfall and alternaria leaf blight of makhana.

have been reported (Sangeetha and Siddaramaiah, 2007). Bhattiprolu and Monga (2018) are also of view that, maximum \&minimum temperatures, number of rainy days and wind speed are the critical parameters for the assessment of alternaria leaf spot of cotton.

\section{Congenial weather parameters and geo-phytopathological model}

To monitor the congenial weather conditions for alternaria leaf blight disease, data pertaining to severity and weather parameters during the study period were pooled. It was assumed that June-August was favorable weather conditions for leaf blight disease occurrence. The weather and their derived parameters for the increased severity of

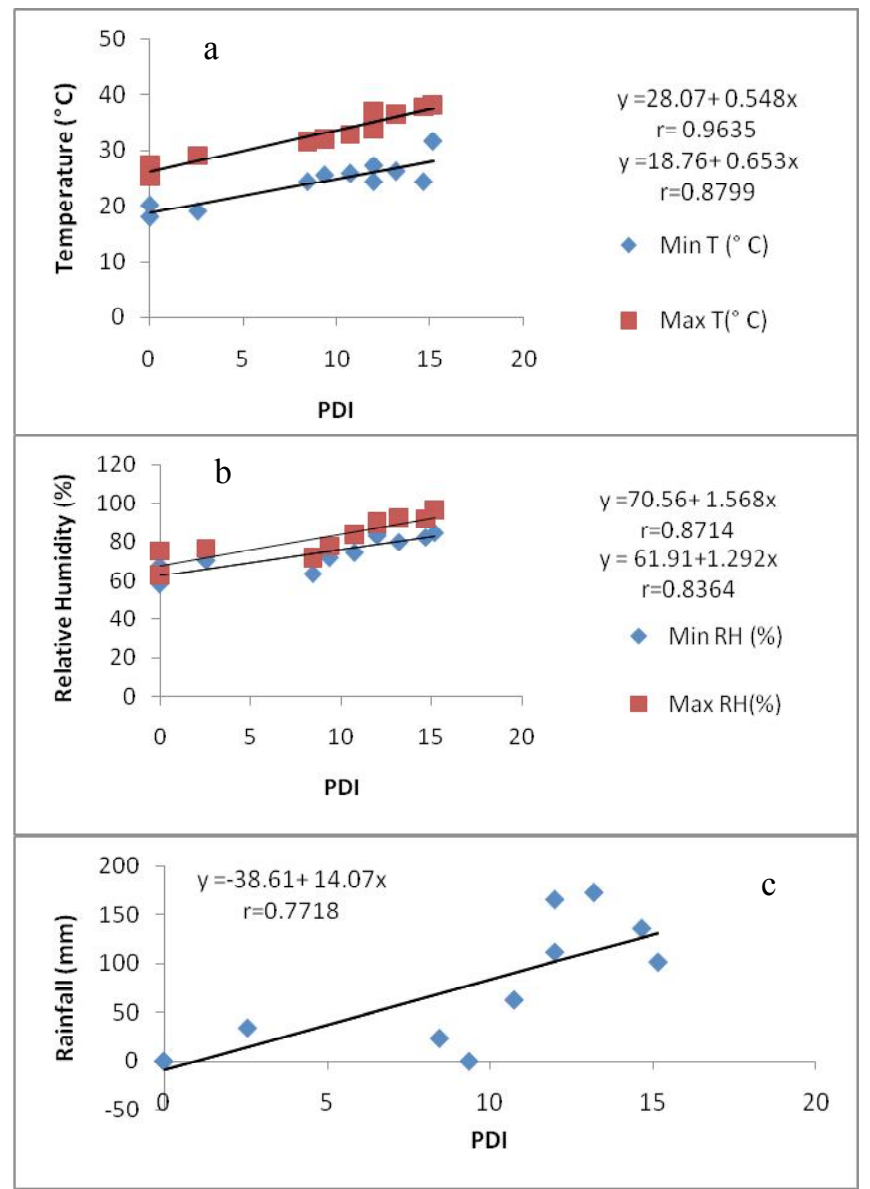

Fig. 4: Relationship between alternaria leaf blight of makhana and weather parameters during 2019;(a) Relationship between temperature and alternaria leaf blight of makhana (b) Relationship between relative humidity and alternaria leaf blight of makhana (c) Relationship between rainfall and alternaria leaf blight of makhana.

leaf blight are mentioned below:

$$
\text { MT } 26.2 \leq \mathrm{MT} \leq 37.4
$$

$$
\text { MRH } 58 \% \leq \mathrm{MRH} \leq 94 \%
$$

HTR $2.6 \leq$ HTR $\leq 3.2$

where MT is mean temperature in ${ }^{\circ} \mathrm{C}, \mathrm{MRH}$ is the mean relative humidity in percentage and HTR is humid thermal ratio during near harvesting stage of makhana.

Average HTR values of both the crop year (2018 and 2019 ) in the Koshi region of Bihar were calculated and on that basis disease severity graph was plotted along with HTR values as shown in Fig. 5 for the development of the geo-phytopathological model. The development of model 


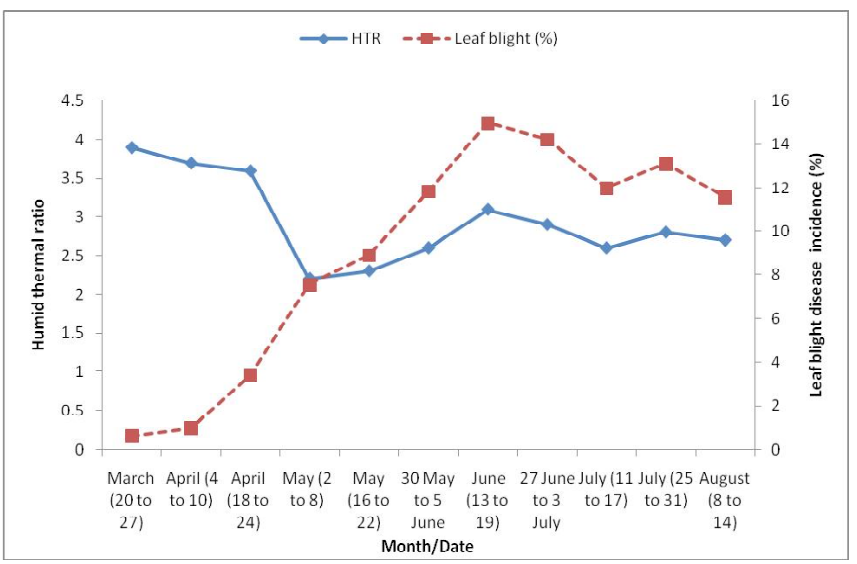

Fig. 5: Pattern of average alternaria leaf blight severity and humid thermal ratio (HTR) of both year 2018 \&2019at Koshi region of Bihar

was carried out on the basis of mean temperature, humidity and HTR. HTR near to 3.0 resultedin a good fit with disease severity percentage. Average maximum disease severity of leaf blight i.e., 14.98\% was observed, when the respective HTR value was 3.1.Close relation of development and prevalence of the ascochyta blight has also been seen in chickpea with HTR values (Jhorar et al., 1997). In other study, validation of the relationship of stem rot and root rot of jute with HTR values in Katihar district (Koshi region) of Bihar has also been explained (Kumar et al., 2017).

\section{CONCLUSION}

Findings of this present investigation reveals that four weather parameters viz., temperature (minimum and maximum), relative humidity (morning and evening), rainfall and eastern wind direction greatly influences the severity of alternarialeaf blight of makhana. Strong positive linear relationship with maximum temperature, relative humidity and rainfall were shown which significantly influences the occurrence of alternaria leaf blight. High disease severity of leaf blight was recorded during the peak monsoon months (June to August). Rising temperature along with relative humidity ( $\geq 90 \%$ ) confers more congenial factors for the occurrence of leaf blight disease. It was also observed that HTR is one of the most suitable parameter to predict the severity of any disease, which delivers under specific weather conditions. Its validation in every location is needed, because a model developed for one location, may not be suitable for other locations. Therefore, we formulated HTR module to predict the severity of alternaria leaf blight of makhana, particularly for the Koshi region of Bihar. This model infers variables such as mean temperature and relative humidity which shows statistically significant correlation with leaf blight of makhana. The data and their analysis resulted from the present investigation also enable the researchers to devise a new system to monitor and develop management strategies for alternaria leaf blight of makhana.

\section{ACKNOWLEDGEMENTS}

Authors acknowledge the financial support of Directorate of Research, Bihar Agricultural University, Sabour to undertake this study and Associate Director Research, Regional Research Station, Agwanpur, Saharsa for technical support in the execution of this research programme.

\section{REFERENCES}

Bhattiprolu, S.L. and Monga, D. (2018). Effect of weather parameters on the development of alternaria leaf spot and greymildew in cotton. J. Agrometeorol., 20(4):315318 .

Chakrabarty, R. (2018). Effect of environmental factors on diseases of betel vine(Piper betle) in Assam. Indian Phytopathol., 71:537-542.

Das Gupta, B. and Sen, C. (1985). Relationship of inoculum density of Colletotricumcapsici and moisture on leaf spot development in betel vine. Indan Phytopathol., $38: 364$.

Dwivedi, A.K., Shekhar, R. and Sharma, S.C. (1995). Ultrastructural studies of Euryale feroxleafinfected by Alternaria alternata. Indian Phytopathol., 48:61-65.

Gomez, K.A. and Gomez, A.L. (1984). Statistical procedures in agricultural research, $2^{\text {nd }}$ edition, Willey, New York, 680.

Haidar, M.G. and Nath, R.P. (1987). Chemical control of alternaria leafblight of Makhana (Euryaleferox). Nat. Acad. Sci. Lett., 10:301-302.

Huq, M.I. (2011). Studies on the epidemiology of leaf rot and leaf spot diseases of betel vine (Piperbetle L.). Bangladesh J. Sci. Ind. Res., 46(4):519-522.

Jana, B.R. (2017). Impact of water depth on growth of gorgon nut and associated weed under wetland ecosystem of North Bihar province in India. J. Crop Weed, 13(1): $77-$ 82.

Jhorar, O.P., Mathauda, S.S., Singh, G., Butler, D.R. and Mavi, H.S. (1997). Relationship between climatic variables and ascochyta blight of chickpea in Punjab, India. Agri. Forest Meteorol., 87:171-177. 
Jhorar, O.P., Mavi, H.S., Sharma,I., Mahi, G.S., Mathauda, S.S. and Singh, G. (1992). A biometeorological model for forecasting karnal bunt disease of wheat.Pl. Dis. Rep., 7:204-209.

Kumar, L., Gupta, V. K., Khan, M.A., Singh, S. S, Janardan, J. and Kumar, A. (2011). Field based makhana cultivation for improving cropping intensity of rice fields. BiharJ.

Hort., 1(1):71-72.

Kumar, S., Md. Nadeem Akhtar., Dayaram, K., M. andKumar, T. (2017). Status of major diseases of jute in Eastern Region of Bihar and correlation of weather parameters with stem and root rot diseases. J. Mycol. Pl.Pathol., 47(2):168-175.

Meena, P.D., Chattopadhyay, C., Meena, S.S. and Kumar, A. (2011). Area under disease progress curve and apparent infection rate ofalternaria blight disease of Indian mustard
(Brassica juncea) at different plant age. Arch. Phytopathol. Pl. Prot., 44(7):684-693.

Sangeetha, C.G. and Siddaramaiah,A.L.(2007). Epidemiological studies of white rust, downymildew and alternaria blight of Indian mustard (Brassica juncea (Linn.) Czern. and Coss.).African J. Agric. Res., 2(7):305-308.

Shankar, M., Chaudhary, N. and Singh, D. (2010). AReview on Gorgon Nut.Int. J. Pharm. Bio. Arch., 1(2):101-107.

Sharma, S.R. and Kolte, S.J. (1994). Effect of soil applied NPK fertilizers on severity of black spot disease (Alternaria brassicae) and yield of oilseed rape. Pl. Soil, 167:313320.

Sindhan, G.S. and Bose, S.K. (1980). Epidemiology of angular leaf spot of french bean caused by Phaeoisariopsis griseola. Ind.Phytopathol., 33:64-68. 